\title{
Comparing the Psychological Aimlessness in Edith Wharton's the House of Mirth and Ernest Hemmingway's the Sun also Rises
}

\author{
Dewi Ulya Mailasari \\ State Institute for Islamic Studies Kudus \\ Jl. Conge, Ngembalrejo PO BOX 51 Kudus, Central Java, Indonesia \\ dewiulya_stainkds@yahoo.co.id
}

\section{Abstract}

Aimlessness concerns about one's existence in a society where somebody feels useless amid the society and doesn't know the role she or he must play. This paper will examine the aimlessness experienced by the main character in the novel entitled The House of Mirth and The Sun Also Rises written by the modernism authors in 1905 and 1926. The first one realized the aimlessness in the very early age, and the life was ended through an overdose, but the later found such feeling after experiencing a war injury. Both characters were victims of the situation but they seemed to have reached a more realistic appreciation of their situation.

Keywords: Aimlessness, Psychological Consequences, Main Characters

\section{Abstrak}

Ketidakberdayaan menyangkut tentang keberadaan seseorang dalam sebuah komunitas dimana seseorang merasa tidak berguna di tengah-tengah masyarakat dan tidak tahu menahu peran apa yang dapat ia lakukan di masyarakat. Penelitian ini bermaksud untuk meneliti pengalaman kehidupan tanpa arah para tokoh utama dalam novel yang berjudul The House of Mirth dan The Sun Also Rises karya pengarang-pengarang modernis di tahun 1905 dan 1926. Pada novel yang pertama mengisahkan tentang ketidakberdayaan seseorang pada usia yang masih sangat belia, dan hidupnya berakhir akibat overdosis; sedangkan pada novel yang selanjutnya mengisahkan tentang perasaan seseorang yang mengalami luka akibat perang. Kedua karakter dalam novel tersebut sama-sama merupakan korban dari keadaan yang mereka alami pada waktu itu, namun mereka justru nampak telah memperoleh hikmah nyata dari keadaan-keadaan yang mereka alami tersebut.

Kata Kunci: Ketidakberdayaan, Dampak Psikologi, Tokoh-Tokoh Utama 


\section{Introduction}

Talking about psychological aimlessness, it concerns about one's existence in a society. He or she feels useless amid the society and doesn't know the role she or he must plays. Therefore the psychological aimlessness refers to one's self-identity as said by Allen Wheelis in The Quest for Identity:

"Identity is a coherent sense of self. It depends upon the awareness that one's endeavors and one's life make sense, that they are meaningful in the context in which life is lived. It depends also upon stable values, and upon the conviction that one's actions and values are harmoniously related. It is a sense of wholeness, of integration, of knowing what is right and what is wrong and of being able to choose"(Wheelis, 1958:19).

When a man grows up and becomes mature, he starts to think about his existence and his life purpose. He looks for a certain view of life that will guide him to his life of the future. Besides, he faces a certain value or social norm prevailed in a society where he lives. If his behavior is in accordance with the value or norm, he will gain a stable social identity.

This paper will examine the aimlessness feeling experienced by the main character in the novel entitled The House of Mirth and The Sun Also Rises written by the modernism authors in 1905 and 1926.

\section{About the authors}

\section{Edith Wharton}

Edith Wharton was a prolific and successful writer. She confirmed her unconventional choice of role as a writer and got a wide public immediately. Neither her parents nor her husband supported her choice. She was a figure who was struggling amid the New York wealthy society and the indifference of everyone who was close to her.

Edith Newbold Jones was born on January 24, 1862 in her parents' house 
in West Twenty-third Street, New York City. Her parents, George Frederic and Lucretia Jones, were descendants of English and Dutch colonists who made fortunes in shipping, banking and real estate. She belonged to the small, most fashionable society of New York which lived on inherited wealth and were interrelated. Her own ancestry was purely middle-class.

The House of Mirth was published in 1905. Louis Auchincloss in Edith Wharton said it: “...marks her coming of age as a novelist."(Auchincloss,1961:11) It was her major piece of work. Compared with the books she had written before, it was with The House of Mirth, her most polished and powerful novel, that she began her career as a portraitist of the upper segments of American society.

\section{Ernest Hemmingway}

Ernest Hemmingway was born in Oak Park, Illiois (outside Chicago) in 1899 and died by suicide in Ketchum in 1861. his father was a doctor and his mother was a singer and teacher of music. Hemmingway's father loved hunting and camping. Some critics say that Hemmingway's father preferred to practice hunting and camping rather than other hobbies because he would try to escape from the gentility and conventionality of his home life and from the dominant cultured and religious standards of Hemmingway's mother. It seemed that Hemmingway's life was influenced by his father's life; Hemmingway was fond of the masculine life of sport and hardship. He rejected the possibility of college education after leaving school. He was involved in the medical grounds for active service in World War I in 1917. he became a newspaper reporter in Kansas City. Then, he became an ambulance driver with the Red Cross in Italy.

During World War I, he suffered a traumatic wound at the front when an Austrian mortar shell exploded close to him and he was then hit in the leg by 
machine-gun fire while carrying a wounded man to safety. He had to be treated in the hospital in Milan for three months.

The next stage in Hemmingway's career was his entry into the professional world of literature. After some time working as a reporter for the Toronto Star and as a journalist in Chicago, he got married. The Sun Also Rises was published in Britain in 1926. Some critics say that the novel became a Bible of a whole generation, a generation that was called "the Lost Generation" by Gertrude Stein. The term began the cult of Hemmingway and of supposed Hemmingway attitudes: the attitudes of the tight-lipped and stoical disillusionment in a world of senseless and sudden violence, the absence of faith but the cultivation of composure, the code of understatement, wry, sardonic wit, and slightly self-pitying "toughness".

\section{The novel structure}

In Dictionary of Literary Terms and Literary Theory, it is said that novel was derived from Italian novella which means tale, piece of news, and now applied to a wide variety of writings whose only common attribute is that they are extended pieces of prose fiction. The prose narrative is about characters and their actions in what was recognizably everyday life and usually in the present, with the emphasis on things being 'new' or a 'novelty' (p.599).

Unlike the short story, it presents more than an episode. In a novel, the author has the freedom to develop plot, characters and theme in detail. The author can also surround the main plot with subplot so that the story becomes longer and complex. Most novels have numerous shifts in time, place, and focus of interest. The authors make use of five main elements; plot, characters, conflict, setting and theme. Some scholars describe plot as the novel's story and its underlying meaning. It is about what happens to the characters and the 
meaning of these events. In relation to the characters, the authors may create characters with complex and complete personalities. In some cases, they even choose to create characters with incomplete personalities. In relation to conflict, it can be physical, emotional, or ethical. It always creates some sort of tension that the characters must resolve. The setting of the novel can be divided into two: setting of time and setting of place. The theme of a novel is the main, major, or central idea that the author wants to convey to the reader. A theme may be explicit, and it may be implicit. The theme of a novel can give greater depth to the novel.

\section{The house of Mirth}

The House of Mirth began with the encounter between Lily Bart and Lawrence Selden. It continued with the other encounters with the other people from upper-class society. In the middle of the story, Lily Bart started to be bored and tired with her society. She felt that everyone seems united to humiliate her. In the end, the author gives the resolution of the main character's problem.

The main characters involve Lily Bart, Lawrence Selden, the Trenors, the Dorsets, and Sam Rosedale. While the supporting characters involve Gerty Farish,, Carrie Fisher, Grace Stepney, Nettie Struther, and the others.

The setting of place is in New York and focused in some houses where the main character ever lived. Each house has a unique characteristic that may represent the different levels of New York people at that time. About the setting of time, it occurs in the first year of the $20^{\text {th }}$ century.

The theme in The House of Mirth is a description about a woman's effort from upper-class who is struggling to be exist amid her society. The author shows that by having self-identity, a woman will have a foothold in the world. 


\section{The Sun also Rises}

The novel is a powerful insight into the lives and values of the socalled "Lost Generation", chronicling the experiences of Jake Barnes and several acquaintances on their pilgrimage to Pamplona for the annual fiesta and bull fights. Barnes suffered an injury during World War I which makes him unable to consummate a sexual relationship with Brett Ashley. The story follows Jake and his various companions across France and Spain.

Initially, Jake seeks peace away from Brett by taking a fishing trip to Burguete, deep within the Spanish hills, with companion Bill Gorton, another veteran of the war. The major conflict was about Jake who was in love with Lady Brett Ashley, but they cannot maintain a relationship because he was rendered impotent by a war wound. Jake loses numerous friendships and has his life repeatedly disrupted because of his loyalty to Brett, who has a destructive series of love affairs with other men. Jake, Brett, and their friends then pursue a dissipated life in Paris; Jake introduces Brett to Robert Cohn; Brett and Cohn have an affair; Cohn follows Brett to Pamplona. The jilted Cohn beats up Mike and Jake, and afterward Pedro Romero. Jake and his friends leave Spain; Jake enjoys the solitude of San Sebastian; Brett wires Jake to rescue her in Madrid after forcing Romero to leave her. The main characters are Jake Barnes, Brett Ashley, Robert Cohn, Michael Campbell, Bill Gorton and Pedro Romero. The setting of time was in 1924, while the setting of place was in Paris, France, moves to Pamplona, Spain, and concludes in Madrid, Spain. The themes of the novel are portrayed by the quotation at the opening of the book: "One generation passeth away, and another generation cometh; but the earth abideth forever. 


\section{Analysis}

\section{The analysis of the House of Mirth}

In this analysis, the psychological aimlessness experienced by the main character, Lily Bart, will be probed through the series of events happened. Lily Bart was deprived of the supports she depends on to sustain her throughout life. She faced the confusion in her attempts at self-identity and her story of love that was also destroyed through these confusions.

The House of Mirth opened with the encounter between Lily Bart and Lawrence Selden. He invited Lily to his apartment and they discussed the various rules of etiquette for young women in the upper-class New York society, the milieu of them both. Lily told Selden that people urged her to get married. Marriage for girls becomes the only way of entering society. In the age of twenty-nine, she was still unmarried. As a woman, Lily was also demanded to look pretty.

While leaving Selden's apartment, Lily met Sam Rosedale, one of the nouveaux riches in New York. She foolishly made a lie by telling that she just came out of her dressmaker in The Bennedick. It was bad to be found out a girl or woman of upper-class like her leaving the bachelor's apartment alone. But Rosedale knew that she lied because he was the owner of the building. It didn't have any dressmaker. Lily was ashamed and leaving him.

In the train, Lily spotted a young milleuner, Percy Gryce. She wanted him to be her future husband. Lily was an orphan at twenty-one years old and now lived with her aunt, Mrs. Peniston. Although she lived well, she felt like to live in a prison because of her aunt's rigidity. So, she associated with her rich friends. She was then unconsciously trapped in the extravagant life-style and as a result, she had too many debts. She found out that her only chance to settle her debts and gain economic freedom was to marry money. 
Lily suddenly became interested in Selden rather than Gryce. It seemed that there was a problem in Lily's personality. She had a desire to join the elite class but on the other hand she also had a desire to avoid the boredom of it.

In a party, Lily was fascinated by the bride's jewels displayed in the party. It could be interpreted that she wanted to be admired but she didn't allow any men to control her feeling.

From the beginning Lily realized that it was her beauty that made her interesting or valuable to others. The man who married her would select her as the final prize in his collection. That was what she felt on Percy Gryce and the men who had proposed her before. But on Selden, she had a different feeling. He possessed the qualities that the other men did not have. Certainly she wanted to be loved by him, for that would confirm her own sense of worth, of lovability. But in order to be worthy of Selden's 'collection', she must not wafer to reject the material world.

Lily learnt that the admiration and excitement she had got during that time was deceit. She must pay them expensively by complying her benefactors' wishes. One of them was Gus Trenor who allowed her some money and then tried to seduce her. Lily was vacillated and she lost her sense of self. Selden didn't even support her.

In the end of the story, Lily was described as drifting aimlessly and fell into lower class. She didn't know what kind of role she must play in her life. Although she fell into poverty, she still followed her inner-self that she would not come back to her old world and became dependent on men economically.

In the Gormers, Lily felt weary in serving her hostess. While she was a taking walk, alone, she felt that her lonely situation seemed to be an escape from the empty noises of her life. Her mind was described as follows: 
"She was weary of being swept passively along a current of pleasure and business in which she had no share; weary of seeing other people pursue amusement and squander money, while she felt herself of no more account among them than an expensive toy in the hands of a spoiled child."(THOM,253)

Her return to the town and not practicing her old habit of life marked her of being excluded from her old society. There was emptiness in hers. The narrator described: "If one were not a part of the season's fixed routine, one swung unsphered in a void of social non- existence"(p.275).

Lily looked for a job and worked as a secretary. Then, she worked in a hat shop and was put to work making hats. Lily was now in the working class environment and lived in a boarding house. She felt strange. After two months, she was still being rebuked for her shoddy work. However, her skills were no use there. In a second rebuke for the same mistake, Lily pretended that she was sick and headed home. She bought some pills because she got insomnia recently.

Lily lost her job at the hat shop as a result of an annual staff reduction. Next morning, as she passed Selden's apartment, in a sudden moment of inspiration, she entered his house. Lily wanted Selden understood that she had tried to become what he wished from her. She said: "I have tried hardbut life is difficult,..."(p.324). Lily also recognized that she was now a useless person, as she said:

"I am a very useless person. I can hardly be said to have an independent existence. I was just a screw or a cog in the great machine I called life, and when I dropped out of it I found I was of no use anywhere else. What can one do when one finds that one only fits into one hole? One must get back to it or be thrown out into the rubbish heap — and you don't know what it's like in the rubbish heap!’(p.325)

At home, she decided to take her chloral sleeping drug more than the 
maximum dosage and drank it.

\section{The analysis of The Sun Also Rises}

Jake's physical malady has profound psychological consequences. He seems quite insecure about his masculinity. The fact that Brett, the love of his life, refuses to enter into a relationship with him compounds this problem. Jake, with typical subtlety, suggests that she does not want to because it would mean giving up sexual intercourse. Jake's hostility toward Robert Cohn is perhaps rooted in his own feelings of inadequacy. In many ways, Jake is a typical member of what poet Gertrude Stein called the "lost generation," the generation of men and women whose experiences in World War I undermined their belief in justice, morality, manhood, and love. Without these ideals to rely on, the Lost Generation lived an aimless, immoral existence, devoid of true emotion and characterized by casual interpersonal cruelty. Part of Jake's character represents the Lost Generation and its unfortunate position: he wanders through Paris, going from bar to bar and drinking heavily at each, his life filled with purposeless debauchery. He demonstrates the capacity to be extremely cruel, especially toward Cohn. His insecurities about his masculinity are typical of the anxieties that many members of the Lost Generation felt.

Yet, in some important ways, Jake differs from those around him. He seems aware of the fruitlessness of the Lost Generation's way of life. He tells Cohn in Chapter II: "You can't get away from yourself by moving from one place to another." Moreover, he recognizes the frequent cruelty of the behavior in which he and his friends engage. Most important, perhaps, he acknowledges, if only indirectly, the pain that his war injury and his unrequited love for Brett cause him. However, though Jake does perceive the problems in his life, he seems either unwilling or unable to remedy them. Though he understands the dilemma of the Lost Generation, he remains trapped within it. 
World War I undercut traditional notions of morality, faith, and justice. No longer able to rely on the traditional beliefs that gave life meaning, the men and women who experienced the war became psychologically and morally lost, and they wandered aimlessly in a world that appeared meaningless. Jake, Brett, and their acquaintances give dramatic life to this situation. Because they no longer believe in anything, their lives are empty. They fill their time with inconsequential and escapist activities, such as drinking, dancing, and debauchery.

It is important to note that Hemingway never explicitly states that Jake and his friends' lives are aimless, or that this aimlessness is a result of the war. Instead, he implies these ideas through his portrayal of the characters' emotional and mental lives. These stand in stark contrast to the characters' surface actions. Jake and his friends' constant carousing do not make them happy. Very often, their merrymaking is joyless and driven by alcohol. At best, it allows them not to think about their inner lives or about the war. Although they spend nearly all of their time partying in one way or another, they remain sorrowful or unfulfilled. Hence, their drinking and dancing is just a futile distraction, a purposeless activity characteristic of a wandering, aimless life.

The world quickly adopted the phrase as the most accurate description of the generation that passed through the threshold of adulthood at this time - working, fighting, or dying in the war. The horrific conflict shattered this generation's faith in -traditional values such as love, bravery, manhood, and womanhood. Without these values, the members of this generation found their existence aimless, meaningless, and unfulfilling. It is these men and women that Hemingway portrays in The Sun Also Rises.

Before the novel opens, Hemingway quotes Stein and a biblical 
passage from Ecclesiastes. The passage contrasts the transient nature of human generations with the eternal survival of nature: the world endures, and the sun continues to rise and set despite the inevitable passage of each human generation into death. Hemingway's juxtaposition of the two epigraphs produces an ambivalent tone. On the one hand, there is hope, because there will be a new generation after the aimless generation that populates The Sun Also Rises. On the other hand, there is bitter irony, since every generation is lost, in the sense that each generation will eventually die.

\section{Conclusion}

The psychological aimlessness experienced by the main character in The House of Mirth can be traced since she was a child. She was brought up to be ornamental and then marrying a rich husband, as taught by her late mother. But there was a moment when she felt tired because she had been long enough in bondage to other's pleasure. Deep inside; she also craved for the assertion of her own eager individuality and the existence recognition. Because of this feeling, she refused some men proposals and went down to the lower-class. She was an unskilled worker and finally jobless. She felt alone and aimlessness. She died of overdose. Although a series of entrapment, betrayal and exclusion in her confining circumstance had been experienced by her, all made her wiser and could see the show objectively.

In The Sun Also Rises, the main character got impotent that made him feels useless and doesn't have life purpose because of war injury. He drank, danced, and traveled to waste the time. It served as metaphors for society's lost optimism and innocence after the war. The war is also present as the tragedy that affects the way characters are able to deal with themselves, and post-war society. Jake Barnes leaves his autonomous position in Paris to join the group on their trip to Pamplona. His experiences there constitute an 
initiation, though not an initiation into the group but an initiation into selfreliance apart from the group. At the end, he renounces the detrimental influence of his friends and especially of Brett. If Brett is the sun of the title around whom the men revolve, he has succeeded in breaking out of the orbit and becoming an independent person (another sun) himself. Ultimately, the novel propagates the self- reliance and autonomy embodied by Romero, the bullfighter whom Jake admires.

Both characters were victims of the situation but they seemed to have reached a more realistic appreciation of their situation.

\section{References}

Hemmingway, Ernest. 1926. The Sun Also Rises. ___ :Charles Scribner's Sons,

Lang, R.D. 1990. in Elizabeth Ammons' A Norton Critical Edition. NY: W.W. Norton \& Company, Inc.

Subhan, Bustami. 2005. Understanding English Poetry and Prose. Yogyakata: LPPDMF.

Waldhorn, Arthur. 1972. A Reader's Guide to Ernest Hemingway. New York: Farrar, Straus, and Giroux.

Wharton, Edith. 1991. The House of Mirth. London: David Campbell Publishers Ltd.

Wheelis, Allen. 1958. The Quest for Identity. NY: W.W. Norton \& Company, Inc. 